\title{
Cohesive Devices Analysis In Abstract Journal Of Premise Volume 6 Number 2 In 2017
}

\author{
Fitri Palupi $\mathrm{K}^{1}$, Rizki Aziza ${ }^{2}$ \\ Muhammadiyah University of Metro \\ fitripalupi85@yahoo.com \\ rizkiaziza97@gmail.com
}

\begin{abstract}
The aims of this research are to explain how reference and reiteration distribute to the text, and also to know the numbers of occurrences and percentages of reference and reiteration found in the text. The subject of this research is 10 Abstracts of PREMISE Journal of English Education Volume 6 Number 2 of Teacher Training and Education Faculty of Muhammadiyah University of Metro summit on October 2017 in Metro, Lampung. The object of this research is components of grammatical and lexical cohesion in reference and reiteration which are developed by Halliday and Hasan. This research is qualitative research. The result shows that almost all elements of the cohesion available in the abstracts. The total number of cohesion in the abstract is 318 ; consist of 254 reference types and 64 reiteration types. The percentages from each type are $9.8 \%$ personal reference, $63.8 \%$ demonstrative reference, and $6.3 \%$ comparative reference in reference types. Besides that, there are $17.3 \%$ repetition, $2.2 \%$ synonymy, $0 \%$ metonymy, and $0.3 \%$ for hyponymy and antonymy in reiteration types. The researcher concluded that the highest cohesive device in the text is a demonstrative reference. The use of cohesive devices found in abstracts is to connect one sentence to another.
\end{abstract}

Key Words: Abstract of Journal, Cohesion, Reference, Reiteration

\section{INTRODUCTION}

Everyone has ways to communicate each other, both in written text, spoken, and in the form of discourse. In some cases, discourse is very important to convey various kinds of information every day, so that readers are more easily understood. (Gee, 2014) Says that Discourse analysis considers how language, both spoken and written, enacts social and cultural 
perspectives and identifies. Likewise discourse analysis is the way people communicate everyday with their own languages and thoughts. Sometimes the people are hard to understand language because of several factors, one of the obstacles is that people have difficulty to understand the sentence meaning. In each related sentence there must be one connector that appears here, so the meaning in the sentence can be conveyed, therefore that is why between the texts there must be cohesion. Cohesion can be interpreted as a tool that can unite text and provide meaning in the text. In this research, the researcher analyzed PREMISE Journal of English Education which publishes results of researches of deep analysis of phenomena on English instructions and education.

This research tries to find the cohesion signals on abstract, because of this section many types cohesion are found, namely reference and reiteration. In this case, reference and reiteration will be focused on abstract in PREMISE Journal of English Education Volume 6 Number 2 of English Study Program of Teacher Training and Education Faculty of Muhammadiyah University of Metro.

Based on the background of the study, the problem of this study can be formulated as follows:

1. How do reference and reiteration distribute to the text?

2. How many numbers of occurrences and percentages of reference and reiteration are found in the text?

\section{LITERATURE REVIEW}

Based on the journal findings, the researcher adapts from those journals about the things related to this research. The first related research is conducted by (Sulistyaningsih \& Slamet, 2018) entitled “An Analysis of Conjunctions Found in Barack Obama's Farewell Speech Text". The next research is from (Pencawan, 2015) entitled "The analysis of Ellipsis and Substitution of YouTube Advertisements". The last research was written by (Nurjannah, 2015) entitled "The Analysis of Repetition in The Body Text of Shampoo Advertisements". Here are some concepts that are used by the researcher; there are the Concept of Cohesion, Types of Cohesion, and Cohesion in Scientific Writing, The Concept of An Analysis, The Concept of Abstract of Journal, and Profile of Premise Journal 
Cohesive Devices Analysis In Abstract Journal Of Premise

Fitri Palupi $\mathrm{K}^{1}$ \& Rizki Aziz ${ }^{2}$

\section{The Concept of Cohesion}

To connect the sentences together, researchers need cohesion. (Suwandi, 2016) Identifies Cohesion may refer to the ways in which sentences are connected by cohesive devices through which readers can perceive the semantic relationship between the sentences. The term cohesion is familiar with language studies. This is part of the language system. This is defined as a resource in a language that provides continuity in the text, exceeding and above that provided by the structure clause and complex clauses. In addition, Halliday and Hasan in (Chasanah, 2009) explain cohesion can be divided into two types: grammatical and lexical cohesion.

\section{a. Types of Cohesion}

Halliday and Hasan in (Bahaziq, 2016) state that there are two types of cohesion, namely: grammatical cohesion and lexical cohesion.

\section{1) Grammatical Cohesion}

(Dewi, 2016) Explains In grammatical cohesion, the relationship between and within a text is signaled by means of grammatical elements. Grammatical cohesion is the combination of sentences that formed by grammatical aspect. So, grammatical cohesion is very important to build sentences in the text so that has a meaning. This includes reference, substitution, ellipsis, and conjunctions.

Adapted from Jan Renkema in (Puspitorini, 2011)

Grammatical Cohesive Devices

$\begin{array}{clll}\begin{array}{l}\text { Reference } \\ \text { - Exophora }\end{array} & \begin{array}{l}\text { Substitution } \\ \text { - Nominal }\end{array} & \begin{array}{l}\text { Ellipsis } \\ \text { - Nominal }\end{array} & \text { - Additive } \\ \text { - Endhopora } & \text { - Verbal } & \text { - Verbal } & \text { - Adversative } \\ \text { Anaphora Cataphora } & \text { - Clausal } & \text { - Clausal } & \text { - Temporal }\end{array}$

Figure 1. Grammatical Cohesion Types

\section{2) Lexical Cohesion}

According to (Baker \& Ellece, 2011) lexical cohesion as a way of achieving cohesion by way of repeating the same word or phrase or using chains of related words that contribute towards the continuity of lexical meaning. Lexical cohesive devices refer to the role played by the selection of vocabulary in organizing relation within a text. It does not deal with the grammatical and semantic connection but with the connection based on the 


\section{INTENSIVE JOURNAL \\ http://ojs.uniska-bjm.ac.id/index.php/EJB \\ October 2019, Vol 2 No.2}

words used. Jan Renkema in (Rohim, 2009) says two types of lexical cohesion can be distinguished: reiteration and collocation.

\section{Lexical Cohesion}

$$
\begin{array}{ll} 
& \text { Reiteration } \\
\text { - } & \text { Repetition } \\
\text { - } & \text { Synonymy } \\
\text { - } & \text { Hyponymy } \\
\text { - } & \text { Metonymy } \\
\text { - } & \text { Antonymy }
\end{array}
$$

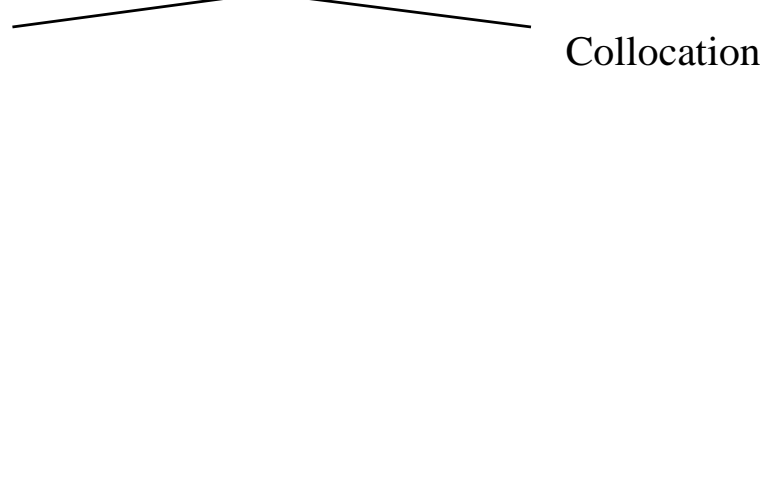

Figure 2. Lexical Cohesion Types

\section{b. Cohesion in Scientific Writing}

(Harmer, 2004) it is imperative to the writer to put cohesive devices to obtain "stick together" within a writing product. In other words, good writing is determined by the presence of cohesive devices. From that explanation, it can be known that cohesion is very important to build the sentences in the text, grammatical and lexical cohesion can make the readers more easily to comprehend the meaning of the text.

(Mack, 2018) Verbalize:

The purpose of a research paper is to present some new result, explain its significance, and place it coherently within the existing body of knowledge. The scientific style, described by its stand on the issues of truth, presentation, scene, cast, and thought and language, creates a unique way of writing that is mostly unfamiliar to the nonscientist. Many common "rules" of good writing (do not use the passive voice, avoid complex noun phrases, and make the action involve people) generally do not apply to the scientific style. In addition, Seow in (Richards \& Renandya, 2002) states that the process of writing comprises of four stages, namely planning, drafting, revising and editing. From this understanding, it can be concluded that writers should need maximum time and energy. Because the writers do 
Cohesive Devices Analysis In Abstract Journal Of Premise

Fitri Palupi $\mathrm{K}^{1}$ \& Rizki Aziz ${ }^{2}$

not only write haphazardly but also in accordance with the expertise and the knowledge which they have. In a discourse, sentences written must be interrelated and have a unified meaning, in order to produce quality writing. In order to be well understood by the reader, cohesion must be determined correctly.

\section{The Concept of Analysis}

Analysis is the study of something by examining its parts and their relationship, (Hornby: 1995). It means that in analysis, the writer should describe all of the phenomena which become the focus in the research.

The researcher concluded that the analysis which is a systematic basic decomposition in determining the part, the relationship between parts is also facilitated to get the right understanding. Moreover, an analysis is an activity that contains a number of activities such as parsing, differentiating, sorting things out to be classified and regrouped according to certain criteria and then looking for their relationships and interpreting their meanings.

In another sense, analysis is an attitude or attention to something (objects, facts, phenomena) to be able to decipher it into parts, as well as knowing the links between those parts in the whole. Analysis can also be interpreted as the ability to solve or decipher a material or find information into smaller components so that it is easier to understand.

\section{The Concept of Abstract of Journal}

According to (Shah, 2017):

The abstract is the 'mini article'. It provides the background, the context, the purpose of the study. Briefly, it describes the methods- where, how the participants were recruited, study design, variables studied, analytical methods and ethical issues. The findings are in line with the objectives and methods and its significance to draw the conclusions. The key words are listed at the end, in the journal style. The abstract is indexed and freely available. Thus, the information must confer to text. There is a word limit, usually of 250 words. Thus it requires time and skill to include important information with a logical flow to 'capture' the essence of the full article. 
In addition, (Koopman, 1997) claims abstracts that have become increasingly important as electronic publication databases are the primary means of finding research reports in a certain subject area today. Therefore, various relevant and crucial summaries must be included in the abstract, as well as to make it easy to read the contents of the results of a study completely and clearly. Because it is short and concise, it only consists of research objectives, methods, results, and conclusions.

\section{Profile of PREMISE Journal}

PREMISE: Journal of English Education (p-ISSN: 2089-3345 and e-ISSN: 2442-482x) is a scientific journal published twice a year in April and October with the number of 12-20 articles per year. It was established on November 2011 for printed and January 30, 2015 for online. The legal standing of this journal is based on issued letter by LIPI under SK no. 0005.006/JI.3.2/SK.ISSN/2011.12 - 5 December 2011 (begun from 5 December 2011) and its barcode 9772089334000 for printed version and issued letter by LIPI under SK no. 0005.2442482X/JI.3.1/SK.ISSN/2015.02 03/1/2015 (18 February 2015) and its barcode 9772442482003 for online version.

PREMISE is managed by the English Education Department Program of FKIP: Muhammadiyah University of Metro (UMM) Metro Lampung, and published by the Scientific Publication Unit of UMM in collaboration with the (Association of English Education Program of Indonesia) in Lampung.

\section{METHODOLOGY}

This research is qualitative research which tries to analyze a discourse. (Hancock, Ockleford, \& Windridge, 2009) State that Qualitative research is concerned with developing explanations of social phenomena. The method employed in this study is the qualitative research, which is descriptive approach. The reason is because the researcher analyzed the data descriptively and the presentation of the result was in a form of explanation of words which would be supported by data presented in the form of tables.

Based on the statement, the researcher will analyze a cohesion analysis component which is developed by Halliday and Hasan. In this case, there are reference and reiteration. The researcher makes some steps to get the data, there are observing, give the coding and marking, identifying and then classifying, categorizing the cohesive devices with numerical number, and then counting the data and the last is concluding the data of the types of reference and reiteration. 
Cohesive Devices Analysis In Abstract Journal Of Premise

Fitri Palupi $\mathrm{K}^{1}$ \& Rizki Aziz ${ }^{2}$

The setting of this research is conducted on PREMISE Journal of English Education Volume 6 Number 2 of English Study Program of Teacher Training and Education Faculty of Muhammadiyah University of Metro. The subject of this research: Abstracts of PREMISE Journal Volume 6 Number 2. The object of this research is components of grammatical and lexical cohesion in reference and reiteration which are developed by Halliday and Hasan. In this case, in the journal, there are 10 selected texts consist of 10 abstracts.

\section{Research Instrument}

Research instrument was the instrument which was used to collect the data in order to reveal the expected answers toward the research problem. Here the researcher has a source so as to search out the data. The researcher has the discourse text in the PREMISE Journals and then analyzes it by herself. The instruments will be supplementary explicated as follows:

\section{a. The Researcher as Human Instrument}

Warren in (Rohmah, 2017) state that in Qualitative research the researcher is the instrument or the tool for designing, collecting, and analyzing research. Theoretical sensitively refers to the personal qualities of the researcher.

\section{b. Tabulation}

Tabulation facilitates in arranging data into rows and column for illuminating data of the research. In this research, tabulation is a tool to separate and to categorize the data based on the characteristic found in the sentences of data source to analyze easily trough table.

\section{c. Documentation}

Documentation used here is all elements of PREMISE Journal of English Education Volume 6 Number 2 of English Study Program of Teacher Training and Education Faculty of Muhammadiyah University of Metro summit on October 2017 in Metro, Lampung, that is in:

\section{http://ojs.fkip.ummetro.ac.id/index.php/english/issue/view/October\#}

After making research instruments, the researcher utilizes the instrument to collect the data. In collecting data, it needs a way to get the data. (Arikunto, 2006).says that in applying documentation method, the researcher is looking for the data about things or variables which are in the form of notes, transcription, book, newspaper, magazine, leaves, etc. (Arikunto, 2006). In this study, the researcher uses indirect observation technique uses internet to get the text of PREMISE Journal. The researcher identifies the point that is relevant to the subject 
matter in order to know the cohesion in the abstract in PREMISE Journals of English Education Volume 6 Number 2.

The data analysis was based on Halliday and Hasan's work of cohesion analysis. After collecting the data by using documentation of PREMISE Journal, the researcher has analysis technique to analyze the data in the form of abstract from PREMISE Journal. Here are the steps to do this analysis:

a. Observing reference and reiteration on grammatical and lexical cohesion in the abstract and give coding and marking.

b. Identifying all the types of cohesive devices within sentences, clause, and paragraphs.

c. Classifying all the types of cohesive devices based on their types and then the classifications will provide in several kinds.

d. Categorizing the cohesive devices, the writer shows the percentage of each type of cohesive devices based on Ali in (Widiasprasetyo, 2013).

$$
X=\frac{\Sigma N}{N} X 100 \%
$$

$X=$ Percentage

$\Sigma \mathrm{N}=$ Types or sub-types of cohesive devices in abstract

$\mathrm{N}=$ Total number of cohesive devices in the abstract

e. Explaining the result and concluding of the analyses descriptively.

\section{FINDINGS}

This section is used to answer the research problems stated, as stated in chapter I, are explored in this chapter. The problem formulations are (1) How do reference and reiteration distribute to the text?, (2) How many the number of occurrences and percentages of reference and reiteration are found in the text?.

Likewise, this is primary step to resolve research question how analysis result of the analysis entitled Abstract Analysis Based on Cohesive Devices (Study on Premise Journal) in Abstract of PREMISE Journal of English Education Volume 6 Number 2 of English Study Program of Teacher Training and Education Faculty of Muhammadiyah University of Metro summit on October 2017 in Metro, Lampung. 
Cohesive Devices Analysis In Abstract Journal Of Premise

Fitri Palupi $\mathrm{K}^{1}$ \& Rizki Aziz ${ }^{2}$

This research is based on Cohesion by Halliday and Hasan. There are 10 abstracts that can be analyzes in the journal, all reference and reiteration types were found by the researcher. The number of all types are 318 consist of reference is 254 , and reiteration is 54 .

Table 1. The Result of Distribution of Cohesion

\begin{tabular}{|c|c|c|c|c|c|c|c|c|c|c|c|c|}
\hline \multirow{2}{*}{ No } & \multirow{2}{*}{ Cohesion } & \multicolumn{10}{|c|}{ Abstract } & \multirow[t]{2}{*}{ Total } \\
\hline & & 1 & 2 & 3 & 4 & 5 & 6 & 7 & 8 & 9 & 10 & \\
\hline \multicolumn{12}{|c|}{ Grammatical Cohesion } & \\
\hline \multicolumn{12}{|c|}{ Reference } & \\
\hline 1. & Per & 8 & 1 & 2 & & 2 & & 12 & 3 & 2 & 1 & 31 \\
\hline 2. & Dem & 18 & 36 & 16 & 22 & 18 & 15 & 19 & 21 & 27 & 11 & 203 \\
\hline 3. & Com & 1 & 2 & 3 & 2 & 2 & & 2 & 1 & 2 & 5 & 20 \\
\hline \multicolumn{12}{|c|}{ Total Reference } & 254 \\
\hline \multicolumn{12}{|c|}{ Lexical Cohesion } & \\
\hline \multicolumn{12}{|c|}{ Reiteration } & \\
\hline 4. & Rep & 7 & 10 & 6 & 4 & 7 & 2 & 2 & 5 & 6 & 6 & 55 \\
\hline 5. & Syn & 1 & & 2 & & 1 & & & 1 & 2 & & 7 \\
\hline 6. & Hyp & & & & & & & & & 1 & & 1 \\
\hline 7. & Met & & & & & & & & & & & \\
\hline 8. & Ant & 1 & & & & & & & & & & 1 \\
\hline$B$. & & & & & & & & & & & & \\
\hline \multicolumn{12}{|c|}{ Total Reiteration } & 64 \\
\hline \multicolumn{12}{|c|}{ Total Reference and Reiteration } & 318 \\
\hline
\end{tabular}

2. The Number of Occurrences and Percentages of Reference and Reiteration Types

Based on the result, the researcher serves the finding of cohesion percentage to make it clearer:

a. References
1) Personal reference
$: \frac{31}{318} \times 100 \%=9.8 \%$
2) Demonstrative reference
$: \frac{203}{318} \times 100 \%=63.8 \%$
3) Comparative reference
$: \frac{20}{318} \times 100 \%=6.3 \%$ 
October 2019, Vol 2 No.2

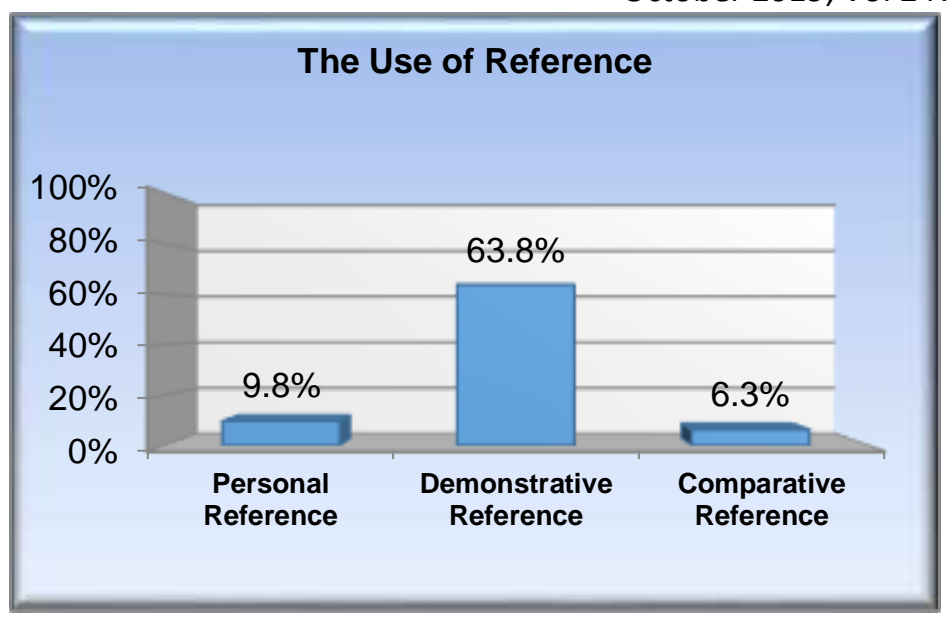

Figure 3. Chart of Reference Types

\section{b. Reiteration}

1) Repetition

$: \frac{55}{318} \times 100 \%=17.3 \%$

2) Synonymy

$: \frac{7}{318} \times 100 \%=2.2 \%$

3) Hyponymy

$: \frac{1}{318} \times 100 \%=0.3 \%$

4) Metonymy

$: \frac{0}{318} \times 100 \%=0 \%$

5) Antonymy

$: \frac{1}{318} \times 100 \%=0.3 \%$

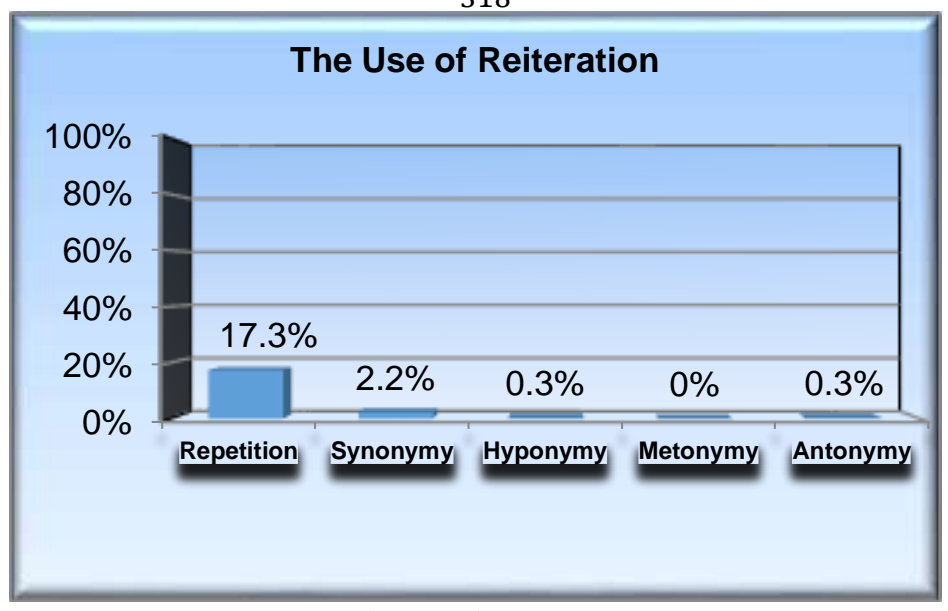

Figure 4. Chart of Reiteration Types

It can be concluded from all of the data above. The researcher found 254 of references, and 64 of reiterations. From the cohesion chart above, that is numeric result of grammatical and lexical cohesive devices in the abstract. There are two kinds of numerical forms used. Those are the real number, and their percentage in comparison with other types.

For the grammatical cohesion in reference types, the percentage of demonstrative reference shows 203 times or $63.8 \%$, the second position is personal reference shows 32 times or $9.8 \%$, and the last position is comparative reference it appears 21 times or $6.3 \%$. Besides 
Cohesive Devices Analysis In Abstract Journal Of Premise

Fitri Palupi $\mathrm{K}^{1}$ \& Rizki Aziz ${ }^{2}$

that, for the lexical cohesion in reiteration used dominantly is repetition. From the percentage above, repetition exceeds 55 times or $17.3 \%$. The second rank is synonymy, it appears 7 times

or $2.2 \%$, the third position is hyponymy and antonymy, those all appear 1 times or $0.3 \%$, the last is metonymy which is 0 time or $0 \%$. Moreover, based on these findings, it can be concluded that the highest type of cohesive devices is demonstrative reference.

\section{DISCUSSION}

From the result of the research, the research analyzes grammatical and lexical cohesion, focus on reference and reiteration types in abstract. In the grammatical cohesion, the researcher found some words in the reference types, there are Personal Reference (Their, They, Them, It, I, Itself, and She), Demonstrative Pronoun (The, This, These, There, That, and Those), the last is Comparative Reference (More, Different, Earlier, Such, Many, So, Same, Other, Differ, and Less). Meanwhile, in the lexical cohesion, especially in reiteration types, the writer found repetition, synonymy, hyponymy and antonymy, nevertheless, there is no metonymy in the abstract.

Besides knowing the distribution of grammatical and lexical cohesion especially in reference and reiteration types, the researcher also calculates the percentages of each type found in 10 Abstracts of PREMISE Journal. The total number is 318; consist of reference types 254 and reiteration types 64 . The result is there are $9.8 \%$ personal reference, $63.8 \%$ demonstrative reference and $6.3 \%$ comparative reference in reference types. Besides that, there are $17.3 \%$ repetition, $2.2 \%$ synonymy, $0 \%$ metonymy, and $0.3 \%$ for hyponymy and antonymy in reiteration types. The researcher finds the grammatical cohesion in reference is demonstrative reference dominantly. Meanwhile, for the lexical cohesion in reiteration is repetition dominantly. The researcher concludes that the highest occurrence cohesive device is demonstrative reference.

Based on the analysis about types of reference and reiteration are found in the Abstract of PREMISE Journal of English Education Volume 6 Number 2 of Teacher Training and Education Faculty of Muhammadiyah University, the researcher make suggestions; they are as follow:

1. For the Students

The researcher suggests the students who write a text should understand the cohesive devices in order to improve their English writing in expressing the ideas clearly. 
2. For the Lecturers

The lecturers can teach adequate cohesive devices. Thus, the lecturer can transfer their knowledge about it clearly. When the researcher did the research, the researcher got difficulties in analyzing the grammatical and lexical cohesion of the text.

3. For the Further Researchers

Hopefully, there will be the next researchers who want to conduct similar research as the researcher did. They can use this research as their previous research. Moreover for the further researcher is in the order they can use different genre in the object of the study. Therefore, the content of the data is different and they will find a different discussion.

\section{REFERENCES}

Arikunto, S. (2006). Prosedur Penelitian: Suatu Pendekatan Praktik (Edisi Revisi IV). Jakarta: PT. Renika Cipta.

Bahaziq, A. (2016). Cohesive Device in Written Discourse: A Discourse Analysis of A Student's Essay Writing. English Language Teaching Journal, Vol. 9. No. 7 pp. 112119.

Baker, P., \& Ellece, S. (2011). Key Terms in Discourse Analysis. London: Continuum International Publishing Group.

Chasanah, N. N. (2009). An Anlysis of Grammatical and Lexical Cohesion in Linkin Park's Song. Surakarta: Muhammadiyah University.

Dewi, D. S. (2016). Analysis of Cohesion on Writing Comparative Paragraph of English Department. JOURNAL ANGLO-SAXON, VOL. 7 NO. 2 (DESEMBER, 2016) pp. 82-87.

Gee, J. P. (2014). An Introduction to discourse Analysis:Theory and Method. Newyork: Routledge.

Hancock, B., Ockleford, E., \& Windridge, K. (2009). An Introduction to Qualitative Research. Sheffield: The NIHR RDS EM / YH.

Harmer. (2004). How to Teach Writing. England: UK: Pearson Education ESL.

Koopman, P. (1997). Retrieved May Wednesday, 2019, from http://users.ece.cmu.edu/ koopman/essays/abstract.html

Mack, C. A. (2018). How to Write A Good Scientific Paper. United States of America: SPIE. Nurjannah, N. (2015). The Analysis of Repetition in The Body Text Of Shampoo Advertisements. Journal of English Language and Learning, 275-282. 
Cohesive Devices Analysis In Abstract Journal Of Premise

Fitri Palupi $\mathrm{K}^{1}$ \& Rizki Aziz ${ }^{2}$

Pencawan, V. D. (2015). The analysis of Ellipsis and Substitution of YouTube Advertisements. Medan: State University of Medan.

Puspitorini, I. (2011). Analysis on Cohesive Devices Used in Descriptive Texts of Senior High School Books. Tulung Agung: STAIN Tulung Agung.

Richards, J. C., \& Renandya, W. A. (2002). Metodhology in Language Teavching. United States of America, Newyork: Cambridge University Press.

Rohim, A. (2009). Cohesion Analysis On The Jakarta Posts's Editorial. Jakarta: State Islamic University Syariif Hidayatullah Jakarta.

Rohmah, J. N. (2017). Framing Analysis of Discourse Why Do British Say 'Sorry' So Much? in BBC Future. Metro: Muhammadiyah university of Metro.

Shah, J. N. (2017). How to Write Abstract For a Scientific Journal Article. Nepal: Journal of Patan Academy of Health Sciences.

Sulistyaningsih, \& Slamet, J. (2018). An Analysis of Conjunctions Found in Barack Obama's Farewell Speech' Text. OKARA: Jurnal Bahasa dan Sastra , 201-212.

Suwandi. (2016). Coherence And Cohesion: An Analysis of The Final Project Abstracts of The Undergraduate Students Of PGRI Semarang. Indonesian Journal of Applied Linguistics, Vol. 5 No. 2, January 2016 , 253-261.

Widiasprasetyo, A. (2013). An Analysis of Grammatical Cohesion Found in Narrative Texts Written By The Second Semester Students of English Education Department of Muria Kudus University in Academic Year 2012/2013. Kudus: University of Muria Kudus. 